\title{
MIXING ETHNIC AND NON-ETHNIC ECONOMIC STRATEGIES: MIGRANT ENTREPRENEURS IN ZAGREB
}

Original scientific paper Submitted: 13. 7. 2018. Accepted: 26. 9. 2018. DOI: $10.15176 /$ vol55no202 UDK 316:331 057.56(497.521.2) $39: 316.334 .56$

\author{
JASNA ČAPO \\ Institute of Ethnology and Folklore Research, Zagreb
}

\author{
PETRA KELEMEN \\ Department of Ethnology and Cultural Anthropology, \\ Faculty of Humanities and Social Sciences, University of Zagreb
}

\begin{abstract}
The article analyses small and medium scale entrepreneurial activities of foreign nationals in Zagreb, the Croatian capital. Migrants' businesses in the hospitality sector are analysed against the background of opportunities and constraints offered by the specific local and national context, and in relation to the city's attempts to reposition itself within international networks of power. The authors argue that the city's ambiguous position - of a national metropolis which lacks relative power internationally and attempts to reposition itself by developing tourism industry - has positive effects on migrants' emplacement. It offers them an opportunity to fill in empty economic niches in the hospitality sector and partake of the current tourist boom and heightened demand for diversity. The article argues that the local context, which lacks international diversity and ethnic markets, does not lead to the creation of "ethnic businesses". By their targeted clientele, workforce, social networking, location in the city centre and visions for business expansion migrant businesses employ mixed, ethnic and non-ethnic, economic strategies of emplacement. The article thus underlines the importance of the local embeddedness for migrants' emplacement, whose constituent part are efforts made by the city at its international rescaling.
\end{abstract}

Keywords: international migrants, migrant entrepreneurship, economic emplacement, city-making, Zagreb

A local walking through the centre of Zagreb, the Croatian capital, would certainly notice that the city has become much more diversified and livelier within the last decade. Various 
public events are staged throughout the year bringing lots of domestic and international guests to the city as well as inciting locals to regularly take part in them. One also hears various languages spoken in the streets and sees groups of tourists getting off buses and being taken along the streets of the two neighbouring historical settlements that form the Upper Town (Gornji grad) that today hosts many state institutions and museums and the bustling late 19th century Lower Town (Donji grad), with its representative historicist buildings, squares and majestic parks. Half a day walking tour would suffice for a tourist to get acquainted with this compact and rather small centre of the Croatian capital, a city with a population of some 800,000 inhabitants.'

In Tkalčićeva street, one of the popular tourist attractions in the Lower Town, one can see a number of international food establishments located almost one next to another: a Turkish, Israeli, two Indian, Greek, Sri Lankan, and Canadian-Croatian street and fast food restaurants. Interspersed with some of the locals' most beloved cafés and bars, these eateries are usually filled with tourists passing through the city. Not far away, there are also a Korean, Spanish, French and African bar/bistro/restaurants, while off the main square one finds a Russian delicatessen shop. There are more such places located just outside of the strictest centre: a Latin American bar, Ukrainian, Asian and Near-Eastern shops, several Chinese restaurants and a Chinese tea house. Further away are a Near-Eastern and Lebanese, Brazilian and a Ukrainian restaurant. In addition to having a fixed emplacement in the city, most of these establishments also take part in the festivals around the city and in other cities and regions of Croatia.

Opened by foreign nationals and Croats from the diaspora, these establishments largely appeared, with some exceptions, in the last few years. Together with several ventures serving international and/or fusion food opened by locals, they have drastically diversified the until recently negligible international food offer in Zagreb. ${ }^{2}$

This article discusses foreign nationals' small and medium-size businesses in Zagreb, focusing on those by means of which they emplaced themselves in a visible way in the city. The businesses include bars, restaurants, shops, hostels, organisation of international shows, teaching martial arts and international dance classes. Migrants' businesses are analysed against the background of economic opportunity structures (mixed embeddedness theory), and the current restructuring of the city and its positioning in relation to other cities. We find that some migrants strategically use their ethnic background to establish a business in the empty economic niche of international food and music. This is parallel to some locals who use the same niche. Both thus fill in the need for more diversity in an ethnically and culturally rather homogeneous capital city of Zagreb at the time of restruc-

\footnotetext{
${ }^{1}$ This article is based on a study carried out with the project "City-making: space, culture and identity", supported by the Croatian Science Foundation (project no. 2350; www.citymaking.eu).

${ }^{2}$ Of the places mentioned above, three closed within less than a year of their operation, which could also signal difficulties in establishing a successful business. This is precisely the issue that we discuss in the article.
} 
turing in the tourism sector. However, we argue that their strategies of emplacement in the city are a mix of ethnic and non-ethnic strategies.

We start by providing statistical data on the city's population, followed by a description of the research participants. Theoretical observations and a presentation of opportunity structures and obstacles to doing business locally follow. The next section provides an ethnographic analysis of migrant businesses. The paper ends with a conclusion on the dynamic relationship between migrants' economic emplacement and the city of Zagreb.

\section{ZAGREB AND ITS SLOWLY GROWING DIVERSITY}

Modest increase in Zagreb's international diversity in recent years can be attributed to the fact that Zagreb and Croatia do not figure on the map of international mobilities. Croatia has traditionally been an emigration country (cf. Župarić-lljić and Bara 2014), which it remains to this day. Negative net migration has been constant since 2009, with a significant rise in emigration after EU accession in 2013 (DZS 2017). Since 2010, the number of immigrants has been on the rise, reaching nearly 14,000 in 2016 (ibid.). With only 3.4 immigrants per 1,000 inhabitants in that year, Croatia ranks among the countries with the lowest number of immigrants compared to the size of the resident population in the EU (Eurostat 2018). The largest share (24\%) of persons who immigrated to Croatia in 2016 was recorded in the City of Zagreb (DZS 2017).

In 2017, the number of foreign nationals living in Croatia with a temporary or permanent residence permit was around 47,500 , which makes for about $1 \%$ of its total population (MUP 2018, our calculation). Out of the total number, 35\% were nationals of the EEA (European Economic Area) countries, 39\% were third-country nationals, and 26\% were family members of the EEA countries' nationals and of Croatian nationals. Among the third-country nationals and among the family members of the EEA countries' and Croatian nationals, the biggest share (in total for these two groups, 78\%) were nationals from the countries of the former Yugoslavia (ibid.).

While the number of foreign nationals in Croatia is very low, they have a very diverse origin: among the 6,500 to 7,000 international immigrants from outside of the EEA and the former Yugoslavia there are persons from over one hundred countries: mostly from China, Russia, USA and Ukraine, but also Turkey, Australia, Canada, Japan, Albania, Korea, Thailand, Nepal, Bangladesh, Sri Lanka, Pakistan, Iran, Congo, Benin, South African Republic, Ghana, Senegal, Ivory Coast, Venezuela, Bolivia, Honduras, Trinidad and Tobago, etc. (ibid.).

The situation in Zagreb reflects the small number of foreign nationals in Croatia, as well as the negative net migration since 2014 (Polančec 2017: 86; DZS 2017). According to the last census (2011), only $0.62 \%(4,871)$ inhabitants of Zagreb have foreign citizenship, 
and 1.97\% (15,586) have dual (Croatian and some other) citizenship (Polančec 2017: 68). Although it has been on the rise, the number of people moving to Zagreb from abroad did not exceed 3,000 until 2016 (ibid.: 86).

In 2017, among temporary residence permit holders in Croatia, ${ }^{3} 23 \%$ were granted temporary residence to be reunited with family members, and 47\% (around 10,500) were granted temporary residence to work (MUP 2018, our calculation). A portion of international migrants enter the country on yearly work permits. In the last five years, official quotas for foreign labour employment varied from 1,700 to 7,050. ${ }^{4}$ The year 2018 brought a significant rise in the quota to 31,000 work permits, most of which were in the following sectors: construction $(10,770)$, tourism and catering sector $(4,660)$, metal industry $(1,600)$, and shipyard industry $(1,408) .{ }^{5}$

In line with the small numbers of foreign nationals, a comprehensive migration policy has been missing in Croatia. The last migration policy was in force until 2015. ${ }^{6}$ Experts have pleaded for a migration policy that would not deal only with legal issues (e.g. visa regimes, acquiring Croatian citizenship, asylum, irregular migration, Croatian diaspora), but that would provide a comprehensive strategy toward migration, in connection with the demographic trends, labour market and overall development (cf. Međunarodna konferencija... 2008; Puljiz et al. 2014). Currently, the large number of people leaving Croatia has once again sparked off demographic projections, scientific analyses, and reactions of the media, politicians and experts. It remains to be seen how these debates on demographic issues, migration policy and the country's economic and social development will be implemented in future policy documents.

When diversity of the city of Zagreb is discussed, it is mostly framed within the context of ethnic minorities and not foreign nationals. The city has historical ethnic, cultural and/ or religious minorities which, as it is stated on the city's web page, "contribute in a special and irreplaceable way to the richness and diversity of the economic, political, cultural and other life in Zagreb"? In 2011, 22 officially recognised ethnic minorities made up $5.26 \%$ of Zagreb's population (Polančec 2017: 69). In a publication dealing with ethnic entrepreneurship in European cities (Rath et al. 2011), with the exception of the Chinese, all other groups specifically mentioned as entrepreneurs in Zagreb are ethnic minorities (Albanians, Bosnian Muslims, Roma) (ibid.: 123).

${ }^{3}$ Family members of the EEA countries' nationals and of Croatian nationals who stay in Croatia on the basis of temporary residence permit are not included in this calculation.

4 2,329 in 2013 (https://narodne-novine.nn.hr/clanci/sluzbeni/2012_12_144_3093.html); 2,256 in 2014 (https://narodne-novine.nn.hr/clanci/sluzbeni/2013_12_151_3188.html); 1,730 in 2015 (https:// narodne-novine.nn.hr/clanci/sluzbeni/2014_12_151_2835.html); 3,115 in 2016 (https://narodne-novine. nn.hr/clanci/sluzbeni/2016_04_39_1027.html); 7,026 in 2017 (https://narodne-novine.nn.hr/clanci/sluzbeni/2016_12_118_2589.html). For an analysis of the annual quota system see Skupnjak Kapić 2014.

${ }^{5} \mathrm{https}$ //narodne-novine.nn.hr/clanci/sluzbeni/2017_12_122_2783.html.

${ }^{6} \mathrm{http}: / /$ narodne-novine.nn.hr/clanci/sluzbeni/full/2013_03_27_456.html.

${ }^{7}$ https://www.zagreb.hr/nacionalne-manjine-u-gradu-zagrebu/676, our translation. 
As of today (2018), the city does not provide statistics about migrant businesses. That may be explained by their small number as well as a complete absence among the city leaders of the idea that international immigration, migrant diversity and entrepreneurship can be advantageous for the city. Foreign nationals are thus excluded from the city's development strategies (cf. Gradski ured... 2017a, 2017b). ${ }^{8}$ That is in opposition to the general acknowledgement of migrants' potential contributions to economic growth and employment (cf. EESC 2012; EC 2013; Kekuš 2017).

While economic activities of ethnic minorities have drawn the attention of researchers (cf. Kuti and Božić 2016; Lekaj et al. 2015; Nreca and Gregov 2018; Rajković Iveta and Geci 2017, etc.), those of migrants, apart from the Chinese (cf. Kuti and Božić 2011, 2016), have been understudied. This article is an attempt to fill in this gap and provide insight into foreign nationals and their entrepreneurial activities in Zagreb.

\section{WHICH FOREIGN NATIONALS?}

Rather than focusing on migrants from the lower (asylum seekers, refugees, low-skilled workers) or higher social positions (highly-skilled executives in transnational enterprises), we focus on an understudied foreign nationals' population in Zagreb - migrants from "middling" social positions or with middle class backgrounds (Favell et al. 2009; Conradson and Latham 2005). According to Favell and colleagues, migrants from middling social positions include "students, nurses, mid-level technical and clerical employees, ambitious or adventurous upwardly mobile middle-classes, migrants from a range of intermediate developing states, and many more it would be hard to describe as 'elites"' (Favell et al. 2009: 2). These individuals present "different types of voyaging", and usually enjoy certain privileges, either in terms of the resources of "money, time and credentials", "relative affluence" or "modest prosperity" (Amit 2007).

The types of voyaging that brought international migrants from middle social positions to Zagreb are dominantly romantic relationships with a Croatian; ${ }^{9}$ remigration from the Croatian diaspora; ${ }^{10}$ student and university teacher mobility platforms; diplomacy whereby after their mission expires people remain; EU nationals in search of a certain "lifestyle" (cf. among other Benson and O'Reilly 2009) most of whom decide to move to places on the Adriatic coast rather than to Zagreb; and, less frequently, small or medium scale business trajectories.

\footnotetext{
${ }^{8}$ One exception are activities focused on the integration of refugees and persons under international protection in the frame of the short-term project "IM.in - Immigrant Integration in Cities of Europe" (https:// www.zagreb.hr/projekt-imin-immigrant-integration-in-cities-of-eu/109928; cf. Gradski ured... 2017a: 507).

${ }^{9}$ Based on this, in one of our previous analyses we named them "love-driven" migrants (Čapo 2018).

10 We can distinguish migrants themselves returning upon retirement and their descendants in the second or third generation who come from countries with a long-established Croatian population such as Argentina, Australia and others (cf. Čapo 2012).
} 
We used a combination of qualitative research methods to gather information about foreign nationals in the city between 2015 and 2018: extensive semi-structured interviews and informal conversations with 50 migrants in public and private settings, and participant observation in their business establishments and during meet-ups and public festivals. In addition, we analysed various media sources (TV series on foreigners, various portals presenting migrants' stories) and several Facebook pages created by migrants (Expats in Zagreb [Official], Internationals living in Croatia) ${ }^{11}$ and migrants' web pages targeting the Zagreb foreign nationals' population like Unique Zagreb. ${ }^{12}$ Continuous following of Facebook activities, linked with a detailed analysis of posts on several occasions has yielded more general information about international migrants in Zagreb, as well as served as a pool for finding research participants (for more details see Čapo and Kelemen 2017, 2018; Čapo 2018).

International migrants to Zagreb (and Croatia) are as "symptomatic of the increasing diversity of contemporary patterns of international migration" as elsewhere (Conradson and Latham 2005: 288), and as such they defy unambiguous categorizations (Čapo and Kelemen 2017). They arrived in Zagreb due mostly to a romantic relationship with a Croatian partner. The latter may have been himself/herself a second/third generation Croat born and raised outside of Croatia or a native to Croatia. Motives for settling are often complex and may involve family circumstances and/or a life transition while being deployed on the background of multiple traveling and sojourning in different countries. After arrival, reasons for staying evolve, and encompass a mix of reasons and images of the country/locality of settlement. A person who came to engage in some kind of economic activity may establish a family locally and stay; a love-driven migrant's relationship may break up but s/he discovers the "amazing local lifestyle" and decides to stay and establish a business; returnees from the diaspora who come for reasons of nostalgia and EU nationals in search of a lifestyle may engage in a business; a person who came for diplomatic or other activity may find a partner and remain, etc. (cf. Čapo 2018 for ethnographic examples).

Foreign nationals in Zagreb are a volatile and in many respects a "super-diverse" group of individuals (cf. Vertovec 2007). A detailed survey of posts from the Expats in Zagreb [Official] Facebook group (done in February-March 2018) confirmed the extremely varied countries of origin and indicated their wide range of occupations which include artists (performance artists, photographers, illustrators, content writers, make-up artists), small craftsmen and product designers (wooden, leather, ceramic products), graphic and web designers and developers, language teachers, interpreters editors/copywriters and

\footnotetext{
${ }^{11}$ Internationals living in Croatia is a rather small and slowly growing Facebook community of foreign nationals spread all over Croatia, with about 1,200 members as of June 2018. In contrast, the Facebook group Expats in Zagreb [Official] has a growing membership: from 1,900 persons in March 2017 it has doubled by June 2018. One should note that not all group members are foreigners living in Zagreb and Croatia; some are planning to relocate, some are locals with international experience (some of whom are spouses of foreign immigrants), some are probably just locals who like to hang around international audiences.

12 This web page (http://www.uniquezagreb.com) is managed by the same person who administers the Facebook group Expats in Zagreb [Official].
} 
freelance (grant) writers, persons engaging in the tourism and hospitality sector (renting apartments, travel agencies with customised tours of Croatia and internationally), (alternative) medicine (acupuncturist, osteopath, physiotherapist, naturopath, herbalist, masseur, healer, chiropractor) and other service sector activities (from hair salons and fitness studios to bar and/or food establishment owners and party/event services), persons working in consultancy, transition management, organisational development, corporate or individual coaching, trade and investment firms, real estate development, wine industries, etc. Most migrants are in independent and creative occupations, many combine a human capital asset (e.g. language) with some engagement locally and are ready to take up several jobs, some secure their living with transnational businesses, some in the informal economic sector.

We do not conceive of migrants as primarily "belonging" to a certain ethnic community and "carrying" certain "ethnic/cultural" markers, as methodological nationalism and the ethnic lens approach to migration would assume (Glick Schiller and Çağlar 2013). Our dissociation from that methodological stance is not only a consequence of the small numbers and diverse origins of migrants in Zagreb which do not allow them to form ethnic communities and neighbourhoods. It is a conscious attempt to move away from the "ethnic gaze" and its assumptions about migrants forming a homogeneous group of people defined in ethnocultural terms (ibid.; Brubaker 2002). Our focus is on migrants' paths of economic emplacement in the city regardless of their origin and ethnocultural background. We understand (economic) emplacement as "a relationship between the continuing restructuring of a city within networks of power and migrants' efforts to settle and build networks of connection within the constraints and opportunities of a specific locality" (Glick Schiller and Çağlar 2013: 495).

Moving away from the ethnic lens also enables us to study migrant entrepreneurship not as "ethnic entrepreneurship" but as a specific type of economic activity practiced by both migrants and non-migrants within a given local context. Focusing on migrant businesses as "ethnic" businesses was an approach developed in the 1970s in the pioneering studies of migrant businesses (Glick Schiller and Çağlar 2013). Migrants were studied by nationality groups, and economic integration was understood as an outcome of the cultural attributes and/or human capital of a specific ethnic group. Their economic activities were studied separately from those of the locals/natives and outside of the effects of the local context. Quite on the contrary, we study them as part of general entrepreneurial activities in a context which, according to both measurable criteria and subjective evaluations (see below), is not conducive to doing business but still due to developing tourist industries offers some opportunities.

We focus on fifteen or so businesses opened by international migrants who have been living in Zagreb from two to more than ten years. They have emplaced themselves in the city in a readily visible way. By relying on migrant culture, they fill a void in the city's multicultural and diversity offer, and together with non-migrants take advantage of the 
growing tourism sector. Though they take inspiration from migrant culture, we argue that the local context of embeddedness does not lead to the creation of "ethnic businesses", i.e. to embeddedness in ethnic communities locally. Such an emplacement is not possible due to the low number of migrants and their diverse origins. According to their target customers, their workforce, social networking and visions for business expansion, migrant entrepreneurs tend to emplace themselves in the city beyond the ethnic niche.

\section{SCALAR POSITIONING, MIXED EMBEDDEDNESS, AGENCY AND MIGRANTS' OWN SCALES}

We analyse migrants' economic activities as they are embedded in local and national opportunity structures (mixed embeddedness theory proposed by Kloosterman 2010; Kloosterman et al. 1999; Kloosterman and Rath 2001; Kloosterman et al. 2016) and use an analytical framework of "multiscalar positioning of cities" which combines migration, urban studies, studies of neoliberalism and studies of post-industrial city restructuring (Glick Schiller and Çağlar 2009, 2011, 2013; Çağlar and Glick Schiller 2018; Glick Schiller 2012).

The mixed embeddedness theory is a "comprehensive analytical framework combining the micro-level of the individual entrepreneur and his or her resources, with the meso-level of the local opportunity structure and [...] the macro-institutional framework" (Kloosterman 2010: 27-28). The mixed embeddedness theory thus combines analysing the valorisation of migrants' capital (resources) and agency in the context of opportunity structures and/or obstacles set by social, economic, and institutional structures of the host society. Host society structures are a broad concept covering a range of host society provisions: from institutional (visa and residency regulations, laws on foreigner settlement and economic activity), economic (market opportunities and/or obstacles, tax regulations, self-employment opportunities, job market, un/employment...), specific locality structures and strategies in dealing with migrants (ethnic neighbourhoods, migrants viewed as an asset or a liability, local and national integration policies aimed at migrants), work ethics and business climate, social relations (family/institutional support, critical mass of migrants and social support, support by diplomatic representatives, local openness to migrants) (Kloosterman et al. 1999; Kloosterman 2010; Kloosterman and Rath 2001; Kloosterman et al. 2016).

In addition, we discuss migrant settlement dynamics informed by theorizing about multiscalar (re)positioning of cities within hierarchies of political, economic and cultural power (Glick Schiller and Çağlar 2009, 2011, 2013; Çağlar and Glick Schiller 2018; Glick Schiller 2012).13 The multiscalar approach focuses on the relationship between migrant emplacement and urban restructuring processes in a particular locality (city) at a par-

${ }^{13}$ The authors sometimes also speak of "multiple embeddedness" (Glick Schiller and Çağlar 2013). 
ticular time while taking into account the city's relative positioning - and its efforts to reposition itself - within changing global configurations of political, economic and cultural power. The approach enables comparative theorizing of locality and migrant settlement: cities of differential relative global positioning are viewed as differential f/actors in migrant settlement in the processes of post-industrial restructuring by which cities aim to rescale or reposition their status and significance both in relation to nation-states in which they are located and within global hierarchies of urban-based institutional power.

The perspective on cities and their dynamic relationship to migrants has a dual significance for our study of Zagreb. On the one hand, by stressing the relative - and changing - positioning of cities within global configurations of power the perspective calls for studying cities and theorizing urban development in cities other than "global" or "gateway" cities like London, Paris or New York. It drew attention to "disempowered cities" or cities marked by a loss in population and a loss of economic, political and cultural power like Halle in Germany and Manchester, New Hampshire in the USA and showed that these cities have impacted their migrant populations differently than paradigmatic gateway cities. While in the latter, the research in the 1980s and 1990s, marked by methodological nationalism, revealed the formation of ethnic (migrant) enclaves and ethnic (migrant) entrepreneurship in the low-wage sector (Glick Schiller and Çağlar 2009, 2013), the more recent research in the former, critical of methodological nationalism and its tendency to study migrants as members/representatives of ethnocultural communities, has revealed a different dynamics: by establishing their businesses, building a worker and customer base with people of diverse ethnic backgrounds, migrants did not seek ethnic but economic visibility in the locality of settlement (ibid.). In this process varying local opportunity structures - or mixed embeddedness - help explain the trajectories of migrant businesses (Kloosterman et al. 1999; Glick Schiller and Çağlar 2013).

Our case study, the city of Zagreb, the capital of Croatia, occupies a different city scale than the above-mentioned cities. Its differential positioning is determined by the articulation of, on the one hand, political, economic and cultural power it occupies within the nation-state in its privileged position as the capital city, and on the other, its relatively weak positioning as a centre of political, economic and cultural power regionally, transnationally (e.g. in the European Union) and globally. This fact has recently prompted city leaders and policy makers to identify Zagreb's comparative advantages, which has relatively successfully rebranded it as a tourist destination (see below). This has opened up some economic opportunities in an economic environment which is otherwise constraining for city residents and immigrants alike. Moreover, Zagreb has its own particular combination of historical and structural/institutional legacies of socialism and post-socialist development which play a key role in the way its restructuring/rescaling processes take place and are lived by its inhabitants, migrants and non-migrants alike. Both the relative scalar positioning of the city and the specific constraints and opportunities of migrants' local embeddedness explain the migrants' presence - or, rather, lack of presence - as well as the particularities of the relationship between the city and its migrants that we discuss in the article. 
Our approach emphasises migrants' agency. Migrants are viewed as actors of city restructuring: they are shaped by the cities' opportunity and barrier structures and they contribute to the cities in which they settle. Migrants "contribute to the positioning of cities in national and global markets and within national, regional and global hierarchies as they labour, produce wealth, raise families, and create and reproduce social institutions" (Glick Schiller and Çağlar 2009: 189). Studying the agency of migrants and, more generally, of all city dwellers in Zagreb was the focus of the project "City-making: space, culture and identity" (2014-2018) within which our research into Zagreb migrants has been conducted. City dwellers were theorized to be not just passive recipients of local structures but city-makers negotiating and recreating the given social, cultural, and spatial landscape of Zagreb, investing it with meaning, restructuring the city and its identity. ${ }^{14}$ Within the framework of the relative scalar approach, city-makers are conceived as "urban scale-makers" (Glick Schiller and Çağlar 2009) in the sense that they participate in the restructuring of the city and contribute to recasting the city's representation and global image. Our findings have led us to an additional understanding of migrants as "scale-makers".

In our previous writings, we have argued that many migrants take an active role in economic, social and cultural transformations of the city and find areas in which they may contribute to the processes of city-making and the repositioning of the city in the international arena (Čapo and Kelemen 2017, 2018; Čapo 2018). Furthermore, they define their own city scales, in which Zagreb occupies a high position relative to its low scalar positioning in terms of global political, economic and cultural power (Čapo and Kelemen 2017). We thus suggest that migrants ranked the city irrespective of its global economic, political and cultural power as a desirable place to settle. ${ }^{15}$ Migrants highly value the city's materiality and aesthetics, character, atmosphere and the "lifestyle" or "way of life" it offers (easy-going, relaxed, slow, walkable, secure city, central European location...) (ibid.). In addition, its low-scale economic positioning in global terms is viewed by migrants as potential and a challenge to respond to, as an invitation to fill empty economic niches and emplace themselves with their innovative ideas. These findings suggest that in studying the processes of reconstitution of the city image it is not only migrants' agency but also migrants' conceptions of desirable and/or attractive city scales - which may not go hand in hand with objectified and measurable economic, political and cultural global positioning of cities - that play a role in migrants' emplacement and determination to make it in the new settlement and thereby contribute to its relative global rescaling.

Let us now see how the overall (national) economic situation, local opportunity structures, obstacles to doing business and institutional framework impact the potential of migrant entrepreneurs to be city-makers.

${ }^{14}$ These lines were taken from the unpublished project proposal "City-making: space, culture and identity" (2013).

15 Migrants' ranking of cities - in terms of their economic, political and cultural power, inspired Nina Glick Schiller to develop the relative scalar approach to the comparative study of cities (Glick Schiller 2012). 


\section{THE LOCAL CONTEXT OF EMBEDDEDNESS}

Recent economic reports have recognised a series of problematic factors and various socio-economic challenges in the Croatian economy. Some of these include: inefficient bureaucracy, corruption, low participation in the labour market, high tax rates and changing tax regulations, restrictive business environment which hinders competitiveness and investment, administrative burden and parafiscal charges, high levels of poverty and social exclusion, structural weaknesses in the education system, etc. (Schwab 2017: 98-99; EC 2018a, 2018b; Singer et al. 2017). Croatia is ranked low on the global scale of competitiveness (Schwab 2017), ${ }^{16}$ and it experiences "excessive macroeconomic imbalances" and insufficient potential growth (EC 2018b: 2). In such an unfavourable business environment, various obstacles to the development of small and medium size enterprises are detected: administrative obstacles (long and expensive procedures for start-up and termination of enterprises), inefficiency of the judiciary, lengthy ownership registration procedures, underdevelopment of informal forms of financing start-up and growth of business ventures (Singer 2017: 37).

A report on the economic situation in Zagreb confirmed the problems identified in the national economy, and detected some specific developmental problems of the city: low GDP compared to similar cities in the EU, low competitiveness compared to other cities, development not sufficiently based on technology and innovations, inadequate measures to include knowledge, technology and innovations into the economy, especially among small and medium entrepreneurs, insufficient focus on foreign markets, etc. (Ekonomski institut 2016: 76). The report also recognised insufficient support for entrepreneurship infrastructure and a lack of professional services offered to small and medium size ventures (ibid.).

Recently, both at the state and the city level, one can observe certain changes in the legislative framework, as well as various initiatives and programmes and different public and private institutions and NGO actors that strive to stimulate entrepreneurship and to create a positive business environment. ${ }^{17}$ Judging by the reports mentioned above, the effect of these various activities has been limited - or they have not yet given results.

${ }^{16}$ According to the World Economic Forum newest report on competitiveness (Schwab 2017), Croatia is ranked as 74th out of 137 countries on the global scale of competitiveness; among the EU countries, only Greece is ranked below Croatia.

${ }^{17}$ For example: Strategija razvoja poduzetništva Republike Hrvatske 2013. - 2020. (https://narodnenovine.nn.hr/clanci/sluzbeni/2013_11_136_2926.html), Zakon o unapređenju poduzetničke infrastrukture (https://narodne-novine.nn.hr/clanci/sluzbeni/2013_07_93_2072.html), South East European Centre for Entrepreneurial Learning, Croatian Agency for SMEs, Innovations and Investments, Croatian Chamber of Economy, different private initiatives and NGOs, etc. One example is Zagreb Innovation Centre (former Development Agency Zagreb), with different programmes aiming to "encourage, guide, and promote entrepreneurial culture and spirit" (https://www.raza.hr/eng), which in May 2018 initiated a project designed for foreign nationals who plan to start a business in Croatia. Since this is a very recent initiative, its concrete effects still remain to be seen. 
Structural reforms have been recognised as the prerequisite for significant positive changes in the overall economic development. For instance, a report of the European Commission states: "Raising potential growth requires structural reforms that will allow for faster productivity growth, higher participation in the labour market, and a business environment that is more attractive for investment" (EC 2018a: 1; cf. Singer 2017: 38).

One economic sector that has been on the rise - which is of significance for our analysis of migrant entrepreneurship in the city - is tourism. Record-breaking statistics have been reported and the importance of tourism for the country's development has been put to the foreground (cf. MT 2018: 2). ${ }^{18}$ Tourism is also regarded as one of the important factors in the development of the Zagreb economy (cf. Gradski ured... 2012; Horwath HTL 2011, 2016). The number of tourists and of overnight stays have been constantly on the rise since 2009 (Polančec 2017: 252-253), the number of tourists doubling in that period. With around 1.3 million tourists in 2017 (which makes around 7.4\% of tourist arrivals in Croatia), Zagreb was the most visited city in Croatia (MT 2018). Tourism growth can also be detected in the increased number of accommodation facilities and businesses registered for accommodation services and catering. ${ }^{19}$ Various events, city-tours, attractions, promotion campaigns, souvenir shops, restaurants and bars, etc. have been designed and developed to attract and welcome domestic and international tourists throughout the year.

Obstacles in the economic and institutional structures enumerated above are relevant for locals and immigrants alike. For immigrants wishing to enter the small and medium enterprise sector these obstacles may even be more challenging given that immigrants struggle with visa and residency issues, with lack of familiarity with local laws and business practices, with not knowing the language or not knowing it well enough to communicate about legal and business issues, with lack of possibilities to obtain bank loans, with legal requirements that immigrant entrepreneurs have to employ a certain number of Croats, ${ }^{20}$ as well as lack of perception of migrants as a developmental factor.

Particularly disadvantaged are non-EU citizens. They are "without the same opportunities for education, training, study grants and public sector jobs as HR [Croatian] citizens"

${ }^{18}$ At the same time, critical voices have been warning that heavy dependence on tourism is risky. A significant share of tourism in the GDP - 18.1\% of revenues in 2015 (in comparison with the average of $2.3 \%$ in the EU) - is seen as a signal of Croatia's non-diversified economy, which together with excessive spatial and seasonal concentration of Croatian tourism represents a specific risk for tourist entrepreneurs and other sectors strongly connected to tourism (HGK 2017).

${ }^{19}$ The number of accommodation facilities: 135 in 2013; 160 in 2014; 190 in 2015; 192 in 2016; 323 in 2017; the number of active businesses registered for accommodation and catering has not been evenly on the rise: 2,561 in 2013; 3,118 in 2014; 3,687 in 2015; 2,541 in 2016; 2,915 in 2017. These data were published in: Gospodarska i društvena kretanja u Gradu Zagrebu, available at: https://www.zagreb.hr/ gospodarska-i-drustvena-kretanja-u-gradu-zagrebu/1042.

${ }^{20}$ Article 78 of the Foreigners Act stipulates that when opening a trading company or sole proprietorship, foreigners and nationals of countries outside the EU must employ a certain number of Croatian nationals (Zakon o strancima, NN 130/2011, http://narodne-novine.nn.hr/clanci/sluzbeni/2011_11_130_2600.html; NN 74/2013, http://narodne-novine.nn.hr/clanci/sluzbeni/2013_06_74_1475.html). Our interlocutors referred to this regulation as well as high taxes when talking about restrictive conditions for opening a business. 
(MIPEX 2015). ${ }^{21}$ Moreover, some temporary workers are "trapped in a job below their qualification because they cannot change jobs and sectors, and access immediate selfemployment" (Vankova et al. 2014: 15). ${ }^{22}$

In order to analyse the relation between immigrants and the labour market, several studies compared the labour market position of native and immigrant population (Botric 2015a, 2015b, 2016a, 2016b). ${ }^{23}$ It was shown that immigrants are predominantly employed in occupations that are in general low-skilled (Botrić 2015a: 54-55; cf. Božić et al. 2013). Moreover, compared with the native population, they face more severe problems in finding work (Botrić 2015a: 59), and they are in a more vulnerable position, with higher unemployment rates and lower employment rates (Botrić 2015b: 207). On the basis of her analysis, the author argued for the inclusion of labour market policy measures into immigration policy.

The mixed embeddedness theory includes perceptions of migrants under local opportunity structures. Therefore, we briefly refer to attitudes of Croatian citizens toward foreigners. The assumption that Croatian accession to the EU would change the country's migration pattern and increase the number of foreign workers was the starting point of a study based on a survey conducted in 2009 (Čačić-Kumpes et al. 2012). The study showed a high degree of resistance towards potential immigrant workers, who were seen as a sociocultural and as a socioeconomic threat, and whose participation in the labour market would have negative consequences for the domestic population. However, a survey conducted in the two easternmost Croatian counties shortly after the Croatian accession to the EU in 2013 contradicted the previous study. It found "that immigrant workers are not perceived as a cultural threat or as a threat to values of the host society. Additionally, in the largest proportions, respondents could accept immigrant workers as their neighbours, guests or even as bosses at work" (Gregurović et al. 2016: 107). In expressing attitudes toward asylum seekers, respondents showed a higher level of hesitation and could not decide whether asylum seekers represented an economic and security threat in the local community, but also rejected the claim that asylum seekers represented a burden for the country's economic development (ibid.: 108-109). Ethnographic research carried out in the same area during the so-called migrant crisis in 2015 , confirmed positive attitudes toward refugees (Čapo 2015). Additional research, which pays attention to possible lo-

\footnotetext{
${ }^{21}$ In 2014, with a score of 54/100 (which is, according to MIPEX legend, "halfway favourable") in terms of labour market mobility, Croatia was ranked as 23 rd out of 38 countries (MIPEX 2015). The overall score of migrant integration policies was $43 / 100$, which ranked Croatia as 30 th out of 38 countries (ibid.). The year before, the score for labour market mobility was 55/100, and the overall score was 42/100 (Vankova et al. 2014: 12-15).

${ }^{22}$ Compare evaluations of the labour market opportunities for 2013: access to the labour market was 70/100; access to general support 50/100; targeted support 13/100; workers' rights 88/100 (Vankova et al. 2014: 14-15). For 2014 the figures somewhat changed, but overall were not any better: access to the labour market 70/100; access to general support 50/100; targeted support 20/100; workers' rights 75/100 (MIPEX 2015). as well.

${ }^{23}$ Botrić's analysis is mostly based on the Labour Force Survey, but complemented with other sources
} 
cal differences and takes into account socio-economic differentiation among migrants, is necessary to be able to reach more conclusive findings on attitudes to international migrants in Croatia.

In summary, various aspects that, according to the mixed embeddedness theory, determine the local and national context of migrant emplacement - economic structures, incentives, regulations, business climate as well as institutional frameworks dealing with migrants (migration policy, regulations and laws) - present numerous obstacles to migrants' emplacement and doing business. The booming tourism industry in the city does offer some opportunities, but even there the general constraints of doing business in Croatia have a constraining impact. However, positive public attitudes toward migrants is an aspect of the local context that may ease their emplacement locally. In the next section we deal with how, in the context of the lack of critical mass of migrants and lack of any numerically significant migrant/ethnic communities, migrant entrepreneurs whom we interviewed are responding to the local economic and institutional constraints and at the same time taking advantage of opportunities offered by the tourism industry.

\section{MIGRANT ENTREPRENEURS IN ZAGREB}

\section{OBSTACLES TO DOING BUSINESS}

The research participants - migrant entrepreneurs in particular - confirm the existence of restrictive opportunity structures and barriers for investment in Zagreb and Croatia. They are general and specific. That Croatia does not have "a very encouraging business environment" or "has never been business oriented" is a frequent general complaint. An immigrant, ${ }^{24}$ who enthusiastically opened an upscale restaurant in Zagreb, which she eventually had to close, was resigned:

It's really difficult for foreigners to start a business in Croatia. That's the only thing I don't like about Croatia. Every country, every European country is very good for business and investment. If someone arrives with money, everyone opens their doors, except in Croatia. Croatia has made everything difficult.

As explained by an immigrant, the difficulties of doing business in Croatia can be explained by local mentalities, historical legacies and a certain misunderstanding of who might be an entrepreneur. All these act as deterrents for engaging in small and medium enterprise activities among locals and impact on the lack of a generally favourable institutional and legal infrastructure and support for these activities. An immigrant, who came for romantic reasons and subsequently co-founded a co-working space which offers incubation and

\footnotetext{
${ }^{24}$ Migrants' names have either been omitted or pseudonyms have been used. However, due to their low number and visibility in public space, these procedures may not fully conceal the identity of the research participants.
} 
mentoring programmes and promotes female, social and youth entrepreneurship, pointed out a local misconception concerning entrepreneurship. In his view, the local understanding links entrepreneurship to connections (social networks) and large investments (and failures which fill national media reports) rather than to ideas, skills, capabilities and opportunities, so that there is a misconception that entrepreneurship is linked to "a sense of entitlement". It would be associated with an alleged local preference to "stick to your comfort zone" rather than dare and step out of the box, to the fear of competition and waiting for opportunities to be offered by the state rather than created by individuals themselves. These historical legacies of the socialist economy are seen by this immigrant as "a problem of the society" that will change with the new millennial generation. ${ }^{25}$ Actually, he sees it already changing under the pressure of high propensity for inventions among Croats that, in his opinion, only needs to be pushed and supported by the state.

The research participants mentioned specific constraining aspects of the local economy and society which make their emplacement difficult: complicated bureaucracy and (constantly changing) regulations; manifold and high taxes and no tax exemptions for new businesses; inconsistent interpretations of laws by various institutions as well as legal advisors whom they hire to help them; lack of coordination between different sectors with which they have to deal and coordinate their activities; information unavailable in English; too many requirements and controlling mechanisms imposed both by the state and the city; until recently limited quotas for foreign workforce; unavailable, unstable and unreliable domestic workforce which lacks appropriate work ethics and professionalism; corruption and difficulties to break through local social networks (see also Čapo 2018; Čapo and Kelemen 2018). This long list of constraining factors confirms the economic analyses and evaluations presented in the previous section: doing business is difficult in Zagreb and Croatia.

Though all migrants agree on critical points of doing business locally, some seem to grapple with them more easily than others. This depends on their previous experience, i.e. where they lived and worked previously. For instance, migrant entrepreneurs from Ukraine, who are among the few who have arrived primarily with the idea to invest locally, claim that they can deal with the difficulties imposed by the local economic and bureaucratic structures, for their reference point is Ukraine where circumstances are tougher:

We used to joke - "Thanks God, we are from Ukraine!" - for whatever we encounter here, in Ukraine it is even more difficult. Here it is not easy. There are grounds that foreign entrepreneurs from Germany or Unites States get scared in Croatia and leave. The bureaucracy is tough here, the legal system also, it is slow, it does not provide support.

Migrants' posts on Facebook about doing business in Croatia were indeed very revealing of the difficulties. They speak of: "a boat load of red tape", "inspectors in Croatia are sort of mafia types...", "between the local government and the tax office things are centuries old,

25 The migrant's observations nicely correspond to several aspects of the egalitarian syndrome theory proposed by Josip Županov (see Štulhofer and Burić 2015). 
and the old mentality of yesteryear is still very strong", "corruption is rife" (cf. Čapo 2018). A migrant from the UK who had to close a cafe summarised all the above-mentioned problems in a comment that exudes frustration and disillusionment and does not give incentives to potential migrant entrepreneurs to invest locally:

In our experience, you need to be prepared to knock on many doors, be delayed at every step, get conflicting information from various bureaucrats and also keep paying for everything before you even start, public notaries, accountants, taxes, work permits and various other permits, licences, attests, sanitary books, the list is never ending. If you do everything "by the book" you won't make any money. [...] we came from the UK feeling very enthusiastic about our new venture and after all the experience we had, we are quite deflated. A lot of time, money, energy wasted. [...] Croatia is a lovely country, people are wonderful and very helpful and we are extremely happy here - just not going to be running a business again - for sure. ${ }^{26}$

\section{MIGRANT CULTURE AS IMPETUS FOR BUSINESS}

In this objectively and subjectively not very encouraging economic environment some research participants still open their own small businesses. Migrant or "ethnic" culture dominates the theme of operation of migrants' businesses visible in the city: migrants exploit their ethnic/cultural background as an economic asset and offer foods, drink, music and other art genres from their countries or broader culture areas of origin. Let us introduce some of the research participants and their businesses.

For example, João came to Zagreb at the age of 26 to teach capoeira. Originally from a small south Brazilian ocean town, this capoeira mestre was sent by his school to start and develop the capoeira scene in Zagreb. Having known, or heard about Croatia via its famous football player Davor Šuker was enough for João, also a keen football player at the time, to say "No problem, I will go". So, the school bought him a ticket, arranged for accommodation and some money to stay in Zagreb for three months "to see if it works" ("da se vidi malo"). The three months turned out into more than ten years, for in the meantime, João has a family locally. His school offers capoeira classes, samba workshops and lessons of Brazilian Portuguese. Since 2008 it has been organising a major international capoeira festival dedicated to the founder of his school, which attracts international public and is claimed to place Zagreb on the European capoeira map. João is occasionally engaged in Brazilian show production/event organisation in and outside of Zagreb. He sees himself as a kind of cultural broker: "I have been diffusing the culture, the Brazilian culture and learning about the Croatian. I live here and have learnt a lot about culture", he said in good Croatian.

${ }^{26}$ A comment on the Facebook group Internationals living in Croatia, May 18, 2016, the comment was added to a post initiated on May 17, 2016. 
The owner of a Turkish restaurant, which was opened seven years ago, also wants to offer more than just "genuine kebab" that was missing in Zagreb when he arrived nine years ago; he serves "the number one brand" of Turkish coffee, and has decorated his restaurant with other "ethnic" items.

During a visit to Croatia, Carmen encountered a man who was to become her husband and cause her to leave her native Cuba and settle in Zagreb. Nostalgia for her native Central America and socializing with "her people" gave her the idea to open a Latin American bar, a kind of establishment, she noticed, that was missing in Croatia. After living in Croatia for five years, Carmen opened a bar at the edge of the narrow centre of Zagreb. The bar is decorated with Cuban paraphernalia (photos, cigars, 1950s American cars), it serves Latin American cocktails, plays Cuban and Latino music, and on the weekends organises parties. The parties have helped the bar create a successful niche in Zagreb's saturated bar market.

Anthony, from Sri Lanka, worked as an IT consultant in various corporate business enterprises, including Microsoft, and lived in the Middle East. Marriage to a Croatian brought him to Zagreb in December 2014. After the dissolution of the marriage soon afterwards, he decided to nonetheless stay in Zagreb, a city that he "really liked. It was one of the main reasons why I stayed". He started a new chapter in his life, changed profession, his residence and his partner. His brother, also a former high profile executive with experience in catering in Sri Lanka joined him, and the brothers opened an Asian curry restaurant in Zagreb in 2015 and have since been developing their own service sector venture, which had turned to a medium-sized one in the meantime, and which now encompasses the original restaurant, a branch opened seasonally on an island, a hostel, and import of Sri Lankan Lion beer. The brothers' vision is to expand internationally.

Two Indian restaurants are less visibly emphasizing their owners' "ethnic" cultures; both are somewhat neutral in decoration but serve Indian food. On its Facebook page, a Ukrainian specialties' shop advertises "Armenian cognac, Moldovan wine, condensed milk and much more" - all products from the former Soviet Union. One of the owners of the store, explained that they started the business selling $90 \%$ of Ukrainian products but switched to selling products from several successor states of the former Soviet Union. He also sees his store as a promotor of these countries: "we try to promote ourselves as much as possible with a certain brand, we try to show that those countries are actually cool, that they have something to offer", he said in fluent Croatian. A Russian delicatessen shop carries similar products from the same region by different producers, while another small shop has a variety of products (from food to hair accessories) from different African countries.

Together with several businesses owned by locals or a combination of a local and a migrant ${ }^{27}$ these migrant businesses fill in the empty niche of international food/drinks/ cultures market in Zagreb. These migrants saw their chance of economic emplacement

${ }^{27}$ For instance, one of the first street food restaurants which offers mainly American dishes (founded jointly by a remigrant from the diaspora and a local), a couple of Japanese restaurants, a South Americanstyle food restaurant, an Asian food store, etc. 
in what some of them label "pioneering" or "different" businesses. It is the very lack of international diversity in the city that becomes an opportunity for migrant emplacement and allows migrant businesses to consolidate themselves by making use of their migrants' culture in the service sector market. By filling the empty niches, migrants are responding both to a local and tourist demand for diversity in the catering sector. Does that make them function as "ethnic businesses"?

\section{BEYOND THE "ETHNIC BUSINESS" CONCEPT}

Given the lack of a critical mass of migrants from any country in the world and the lack of migrant ethnic communities and markets, migrant businesses in Zagreb can only be called "ethnic" in the sense that they exploit migrants' cultural background. In other respects - in terms of the workforce they employ, the clientele which they target, social networking in which they engage and plans for transnationalization of their activities - they go beyond the ethnic concept. They employ mixed business strategies to establish and consolidate their businesses in the local environment. This finding thus supports theories which stress the importance of the local context for migrant economic emplacement. Let us see how migrants strategize in order to make their businesses viable in the almost complete absence of co-ethnic populations locally.

One of the strategies is securing tourists and/or local customers. For example, a Korean restaurant caters primarily to its own mobile co-ethnics, Korean tourists, who started visiting Zagreb a few years ago, after the production of a well-known Korean TV series in Croatia. The Korean market in Zagreb was at its peak about a couple of years ago, when two restaurants and a shop, a hotel and several apartments designed specifically for the growing number of Korean tourists were opened (by Koreans living in Zagreb and by mixed Croatian-Korean couples). Meanwhile, one restaurant and a shop closed down.

Indian restaurants are in a somewhat better position with regard to transient customers, tourists. Globally and not only in the United Kingdom and in other countries of the British Commonwealth, Indian food has become part of everyday diet, which means that the two Indian restaurants need not depend only on Indian visitors but can also benefit from tourists from a wide variety of countries having affinity to Indian foods. However, together with the Korean restaurant, the two Indian restaurants might have difficulties in a scenario of declining tourism, even if they are profiting from local diplomatic representation and networks and to a certain extent from the locals. Too heavy a reliance on the current tourist momentum - and more specifically on their own co-ethnic tourists - could prove detrimental if tourism declines, like in the case of the failed Korean restaurant and shop. This is why one Indian restaurant is doing its best to attract local customers.

Targeting the locals as a strategy to secure economic viability is not without its own intricacies. According to the research participants' perception, the locals are "conservative in certain things" and not prone to experimenting with unknown tastes. So how can migrant 
businesses attract them? The "migrant culture" that is offered has to have a global and/or regional appeal or somehow be familiar to the locals. The Brazilian capoeira or Latin American music are examples of globally distributed and popular cultural items whose appeal goes beyond narrow ethnic and cultural boundaries and thus finds customers in Zagreb. This is obvious in the case of the Latin American bar, but also in João's case. He is able to "sell" (more or less successfully) a globally popular Afro-Brazilian martial art that combines elements of dance, acrobatics and music as well as Brazilian shows with different contents.

The owner of a Turkish restaurant tells a different story. He needed some time to establish his restaurant in the city; in his case, the popularity of Turkish soap operas in Croatia supposedly reversed the negative image of the Turks in the Croatian society and brought local customers to the restaurant. To capitalise on the sudden popularity of Turkish soap operas and the reversal of the popular perceptions of the Turks, the owner even named a dish on the menu after a character from a Turkish soap opera.

A different rationale for attracting local clientele underlines the Ukrainian and Russian shops. They secured local customers thanks to these countries' socialist/communist background which is shared by Croatia, itself a former republic of the socialist Yugoslavia. Some products sold in these stores have been established locally since long ago: among others, Armenian brandy ("cognac") or Russian vodka and caviar. In addition, some items might have a popular culture appeal, like the calendar with photos of the Russian president, which, thanks to Putin's celebrity status, got sold in record time, not only to Russian speakers in Zagreb but also to locals.

Some businesses secure their sustainability by the choice of location of the business in the urban space. As mentioned at the beginning of the article, most foreign nationals' establishments occupy places within the centre on or nearby main tourist attractions. Those located on Tkalčićeva street, a bustling tourist street, ${ }^{28}$ claim that the street itself is "a bomb" that will assure their success. That is why an Indian restaurant recently moved there. To increase their presence outside of the main establishment and attract more customers, some businesses regularly take part in urban festivals, like the Christmas market or the festival of international food, "World on the plate", at which they open temporary outlets (stands). Some open a branch at the seaside, during the tourist season.

Migrant entrepreneurs may also turn to diversification as a business strategy. In addition to having a restaurant they open an ethnic-foods store or vice versa - in their store they sell home-made "ethnic" dishes. They become exclusive importers of products from their home countries that they distribute locally and serve in their restaurants (e.g. beer, coffee, spices). Some engage in a variety of other activities to supplement the income gained from the core business. For instance, João engages in a range of other jobs to support himself and his family. He has worked as a bartender in various places (among other in a short-lived Brazilian restaurant), in Brazilian show production/event organisation in and

28 https://www.tripadvisor.com/Attractions-g294454-Activities-Zagreb_Central_Croatia.html\#ATTRA CTION_SORT_WRAPPER - on 14/5/2018 Tkalčićeva is ranked as: \#6 of 246 things to do in Zagreb. 
outside of Zagreb (and internationally), as a waiter and/or animator during the summer tourist season on the coast. After completing a course of Croatian, Ines who was born to Croats living in Peru, decided to stay in Zagreb. Currently she gets on by doing different jobs: teaching Spanish and developing her little craft with personalised coffee cups while at the same time she is thinking of opening a Peruvian restaurant or a coffee bar.

Diversification of jobs is a strategy employed by other migrants, also those whose core profession/job does not primarily rely on migrant culture. A case in point is an Australian street performer who used to perform on the main square before the city banned his performances from it. This forced him to mainly perform abroad and seasonally in Croatian towns at the seaside. In addition, this versatile man engages in an impressive list of jobs:

I am an entertainer. Comedy juggler if you want to be specific. That has been my main profession for most of my life. When I don't do that, I consult and coordinate with festivals. I have proof read and edited a number of English documents written by Croatians. I am also a cabinetmaker/product designer, prop maker, builder, Brewer, jack of all trades. ${ }^{29}$

While the street performer already works internationally, some restaurant owners are considering to transnationalize. After having successfully expanded in Croatia (by opening branches outside of Zagreb), they now have plans to expand abroad, most likely to Vienna or Budapest.

Two migrants' businesses have gone beyond the ethnic theme and developed different concepts in their restaurants. The couple from Ukraine, who are among the rare migrants who came specifically with the intention to invest in Croatia, took an informed decision to settle in Croatia where they planned to open "a restaurant network with incredible and delicious cuisine". In spite of being told that "Croatia is tough for business", after investigating the Croatian hospitality sector and habits of the population they concluded that the best place to open their "modern bistro" with "interesting casual food" was Zagreb. The wife was confident of their success and enthusiastically engaged in branding the restaurant as an up-scale place with a touch of homely and cosy atmosphere. It also offered special food-and-literature events and arranged for a free book exchange on its premises. Although gaining reputation, the restaurant closed within less than a year since its opening. From the owners' sparse comments it can be inferred that the location of the restaurant (outside of the narrow city centre) as well as the mid-range and upscale clientele that it targeted - which it did not find to a sufficient extent - were the main reasons for the decision to close. One may hypothesize that this was compounded by numerous factors which constrain economic activities.

In contrast, the Sri Lankan-owned street food bistro turned out to be a very successful business. With lots of media attention given to its owners, it soon became popular. The

${ }^{29}$ Facebook Expats in Zagreb [Official], the post asking expats to name their trade was initiated by the administrator on November 6, 2017. 
owners used their migrant background as a springboard for developing a restaurant which uses the "ethnic"/"cultural" only as the backbone of their entertainment oriented service businesses that they have been developing in the past three years. From the beginning, their idea was not just to serve spicy Asian food, but also to offer entertainment and add a personal touch to what they do. One of them explains that their concept is about making

you laugh, make a connection with you, it's about very specific music; we offer experience which is not just about food, it's about spending good time here. It's in a great location and people come here and want to enjoy.

They applied a similar concept in their hostel. The hostel offers not only (cheap) accommodation but also "experience, meeting people and exploring together". Judging by the fact that within a year of its operation the hostel became very popular it appears that the brothers have successfully applied this concept in Zagreb. The two businessmen also strive to offer a fair, enthusiastic, friendly, incentives and career-oriented working environment for their staff (unlike many businesses in Croatia they pay wages and bills on time, thereby gaining a good reputation both among workers and cooperation partners), which they make part of their successful business concept. This may be another strategy that explains the success of this rapidly growing migrant business. ${ }^{30}$

Finally, social networks also help migrant businesses to successfully emplace themselves. Supportive social networks are of different kinds, location and reach. Some are transnational, as when the family at home is backing the migrant's business locally. Local support networks are of two kinds: one consists of migrants' countries respective diplomatic representation (which supports the opening of an establishment, brings their guests, etc.) and, through it, of diplomats from various countries who become customers. The other local support network goes beyond the ethnic concept. It encompasses migrant and non-migrant businesses alike. This is the case of the informal support group founded by entrepreneurs on the Tkalčićeva street regardless of their migrant or local origin. With a common economic interest, entrepreneurs who joined the group exert pressure on the city bureaucrats regarding certain aspects of the location (e.g. better appearance of the street, flower pots uniformly aligned along the street, the street's inclusion in major city festivals, etc.) and lobby state decision-makers to lower service-sector taxes ${ }^{31}$ and increase quotas for foreign workers. Their joint action seems to have been successful - the city tourist board staged Christmas market events on Tkalčićeva street in 2017, which had not been the case in previous years. The research participants have praised such joint efforts of business owners from the street.

${ }^{30}$ Emphasising and utilising a specific work-ethics is akin to the perception by migrant entrepreneurs (e.g. from Turkey and Sri Lanka) that they come from "a culture of entrepreneurship", that they have applied in an environment without such a culture/tradition.

${ }^{31}$ They doubled in 2017, from 13 to $25 \%$. 


\section{CONCLUSIONS}

The research confirmed the importance of examining migrants' economic emplacement in the light of both constraints and opportunities offered by a specific urban and national context (as proposed by the mixed embeddedness theory), and city's attempts at repositioning itself within international networks of power (as proposed by the relative cities' scalar positioning theory).

According to various objective criteria and analyses, the economic environment and opportunity structures in Zagreb and Croatia are unfavourable to doing business. This is due to historic institutional legacies, a long list of administrative, legal and tax constraints on economic activities, changing regulations, a growing lack of workforce, misconceptions about small entrepreneurship, etc. These factors affect migrant and non-migrant businesses alike. Migrants' experiences and evaluations of the obstacles encountered in the process of establishing themselves in the city go hand-in-hand with economic reports on constraining local and national economic opportunity structures.

Migrants have an additional institutional constraint on their small and medium-size investments because of certain requirements on foreign nationals (a certain number of locals have to be employed per foreign national entrepreneur), additional administrative procedures that they have to undergo and no city (and national) strategies targeting migrants (except for a recent rise in the quota of work permits for foreigners). This makes migrants' stakes even higher and odds for economic success more difficult than for the locals.

Another factor in understanding the specifics of migrants' emplacement in Zagreb is its relative scalar positioning. Zagreb is by no means a paradigmatic gateway city, a city of high finances and capital investments, or a city positioned high on the hierarchies of political and cultural urban power. But it is also not a disempowered city, similar to those that were studied as part of theorizing about comparative city scales and the emplacement of migrants. Zagreb has an ambiguous position: it is also a city that occupies a metropolitan status in the national arena. That fact alone makes it into a powerful financial, political and cultural centre locally. However, the city has a very different position internationally: the lack of relative power in any of the relevant domains (political, economic, cultural) is visible, among other things, in the fact that it does not attract migrants. Persons who settle in Zagreb are practically accidental migrants: most are love-driven migrants or members of the Croatian diaspora who decide to return or resettle.

The city's ambiguous position has positive effects on migrant emplacement: it offers them an opportunity to fill in empty economic niches in the catering sector. It is not surprising that in the absence of international diversity, migrants are settling in businesses that introduce their migrant cultures to the local scene. In addition, the city has recently embarked on a campaign to reposition itself on comparative international city scales. This has been done by rebranding the city as a tourist destination and developing tourism industries. If measured by certain indicators (number of visitors, number of overnight stays in Zagreb) the campaign has raised the touristic profile of the city. Global increase 
in mobilities, as well as contingencies such as local film productions by international companies (in Korea and India), have further raised the city's touristic attraction for certain mobile nationals. These developments present the most important opportunity structure for establishing migrants' businesses in an otherwise constraining economic environment.

This development has another interesting twist in the local context: under the conditions of a practical lack of international migration in the city and migrants' extremely diverse origin, the local context cannot produce ethnic communities so that the established migrant businesses are forced to resort to mixed, ethnic and non-ethnic, economic strategies of emplacement in order to sustain themselves. The migrants' businesses which had visibly emplaced themselves in the city have used the migrant culture as a resource and offer "ethnic" foods, drinks, dances, world music, and martial arts. In the process of emplacement, they strategically use their ethnic background to establish their business, because the city has a demand for such businesses. Their other strategies of emplacement include location in the city centre, diversifying the targeted clientele (locals and tourists), diversifying investments and activities, developing beyond-the-ethnic concepts of the establishment (e.g. entertainment), forging local social networks with non-migrant entrepreneurs, and transnationalization of the business.

The strategies are combined in different ways. We would say that the best combination proved to be the one which uses a central city location together with business diversification and a dedicated building of an encouraging business environment. Previous business experience and larger capital investments also play a role. The effects of these strategies are combined with the effects of the recently booming tourism industry which created a demand for more diversity in the service sector.

This study underlines the importance of the local embeddedness context for migrants' emplacement. It also shows that the local embeddedness context itself is partly an outcome of the specific international positioning of the city and its efforts at rescaling at a particular point in time. By relying on "migrant/ethnic culture" in their business but seeking a mix of ethnic and non-ethnic economic strategies, migrants in Zagreb respond to the specificities of the local embeddedness context which does not exhibit migrant/ethnic diversity, lacks ethnic markets and does not seek out further ethnic and culture diversity by attracting migrants and recasting itself as a multicultural, diverse city.

Finally, we would like to point out some differences between migrants' emplacement in Zagreb and other cities positioned on lower ends of international city scales. In Zagreb, migrants use ethnic/migrant culture as a resource only to go beyond it. In Halle (Germany), studied by Glick Schiller and Çağlar $(2009,2013)$, they engage in non-ethnic businesses. The difference is caused by different local embeddedness contexts and cities' strategies for restructuring the city. In Halle, migrants were invited by the city leaders to settle and engage in non-ethnic businesses; in Zagreb there was no support by the city leaders for migrants to settle, do business and become city-scale makers. However, in the context of specific economic opportunities and constraints nationally and locally, migrants found their own way of establishing themselves by combining ethnic and non-ethnic strategies 
in their ventures. Tourist development, as well as local demand for diversity in the service sector, pushed them toward exploiting ethnic/cultural themes in their businesses. At the same time, the local embeddedness context limited the opportunities offered by ethnic emplacement and they had to combine it with non-ethnic economic rationality and strategizing. Migrants' agency in Zagreb is therefore similar to those of non-migrant actors. The fact that they share similar concerns, obstacles and opportunities is visible in their forming joint support networks with pressure/lobbying intentions locally and on the state level as well as in the failures of businesses founded by migrants and non-migrants alike.

\section{REFERENCES AND SOURCES}

Amit, Vered, ed. 2007. Going First Class? New Approaches to Privileged Travel and Movement. New York, London: Berghahn Books.

Benson, Michaela and Karen O'Reilly. 2009. "Migration and the Search for a Better Way of Life. A Critical Exploration of Lifestyle Migration". The Sociological Review 57/4: 608-625. https://doi.org/10.1111/ j.1467-954X.2009.01864.x

Botrić, Valerija. 2015a. 'Immigrants' Characteristics and the Croatian Labour Market. An Explorative Study". Migracijske i etničke teme 31/1: 39-63. https://doi.org/10.11567/met.31.1.2

Botrić, Valerija. 2015b. "Relative Labour Market Outcomes of Immigrants in Croatia". Economics and Sociology 8/3: 197-214. https://doi.org/10.14254/2071-789x.2015/8-3/15

Botrić, Valerija. 2016a. "Attitudes Towards Immigrants, Immigration Policies and Labour Market Outcomes. Comparing Croatia with Hungary and Slovenia". CIRR22/76: 5-28. https://doi.org/10.1515/ cirr-2016-0004

Botrić, Valerija. 2016b. "Nezaposlenost i dugotrajna nezaposlenost doseljenih u Hrvatsku” [Unemployment and Long-Term Unemployment of Immigrants in Croatia]. Migracijske i etničke teme 32/1: 63-89. https://doi.org/10.11567/met.32.1.3

Božić, Saša, Boško Kuzmanović and Valerija Barada. 2013. "Strani radnici u Hrvatskoj. Porijeklo, status, orijentacije" [Foreign Workers in Croatia. Origin, Status, Orientation]. Migracijske i etničke teme 29/3: 367-404. https://doi.org/10.11567/met.29.3.3

Brubaker, Rogers. 2002. "Ethnicity without Groups". European Journal of Sociology 43/2: 163-189. https://doi.org/10.1017/S0003975602001066

Conradson, David and Alan Latham. 2005. "Friendship, Networks and Transnationality in a World City. Antipodean Transmigrants in London". Journal of Ethnic and Migration Studies 31/2: 287-305. https://doi.org/10.1080/1369183042000339936

Čačić-Kumpes, Jadranka, Snježana Gregurović and Josip Kumpes. 2012. "Migracija, integracija i stavovi prema imigrantima u Hrvatskoj" [Migration, Integration, and Attitudes towards Immigrants in Croatia]. Revija za sociologiju 42/3: 305-336. https://doi.org/10.5613/rzs.42.3.3

Çağlar, Ayşe and Nina Glick Schiller. 2018. Migrants and City-Making. Dispossession, Displacement, and Urban Regeneration. Durham, London: Duke University Press.

Čapo, Jasna. 2012. “The World Is My Oyster'. Well-Educated Australian-Croatian Citizens in the Era of Global Mobilities". Croatian Studies Review 8/1: 91-112.

Čapo, Jasna. 2015. “Od Opatovca do Strasbourga. Razna lica izbjegličke “krize”" [From Opatovac to Strasbourg. Various Faces of the Migrant "Crisis"]. Zbornik Trećeg programa Hrvatskog radija 87: 5-17. 
Čapo, Jasna. 2018. "Economic Activities and Agency of 'Love-Driven' International Migrants in the City of Zagreb". In Contemporary Migration Trends and Flows on the Territory of Southeast Europe. Marijeta Rajković Iveta, Petra Kelemen and Drago Župarić-Iljić, eds. Zagreb: FF-press. (in print)

Čapo, Jasna and Petra Kelemen. 2017. "Zagreb očima međunarodnih migranata. Značenja, potencijali i (re)skaliranje grada" [Zagreb through the Eyes of International Migrants. Meanings, Potentials and (Re)scaling of the City]. Studia ethnologica Croatica 29: 251-277. https://doi.org/10.17234/SEC.29.9

Čapo, Jasna and Petra Kelemen. 2018. The City and International Migrants. Zagreb: Institute of Ethnology and Folklore Research. Available at: http://www.citymaking.eu/en/the-city-and-international-migrants/.

DZS - Državni zavod za statistiku Republike Hrvatske. 2017. Migracija stanovništva Republike Hrvatske u 2016. / Migration of Population of Republic of Croatia, 2016. Zagreb: Croatian Bureau of Statistics. Available at: https://www.dzs.hr/Hrv_Eng/publication/2017/07-01-02_01_2017.htm.

EC - European Commission. 2013. Entrepreneurship 2020 Action Plan. Reigniting the Entrepreneurial Spirit in Europe. Brussels: European Commission. Available at: https://eur-lex.europa.eu/legal-content/EN/TXT/?uri=CELEX: 52012DC0795.

EC - European Commission. 2018a. Country Report Croatia 2018. Including an In-Depth Review on the Prevention and Correction of Macroeconomic Imbalances. Brussels: European Commission. Available at: https://eur-lex.europa.eu/legal-content/EN/TXT/PDF/?uri=CELEX: 52018SC0209\&from=EN.

EC - European Commission. 2018b. Recommendation for a Council Recommendation on the 2018 National Reform Programme of Croatia and Delivering a Council Opinion on the 2018 Convergence Programme of Croatia. Brussels: European Commission. Available at: https://eur-lex.europa. eu/legal-content/EN/TXT/PDF/?uri=CELEX: 52018DC0410\&from=EN.

EESC - European Economic and Social Committee. 2012. Opinion of the European Economic and Social Committee on "The Contribution of Migrant Entrepreneurs to the EU Economy" (Own-Initiative Opinion). Available at: https://eur-lex.europa.eu/legal-content/EN/TXT/PDF/?uri=CELEX: 52012IE0638\&from=EN.

Ekonomski institut, Zagreb. 2016. Polazne osnove za izradu Strategije razvoja Urbane aglomeracije Zagreb - gospodarski aspekti [Starting Points for the Development of the Zagreb Urban Agglomeration Strategy - Economic Aspects]. Zagreb: Ekonomski institut. Available at: https://www.zagreb.hr/ UserDocsImages/arhiva/PRILOZI\%2OEIZ-FINAL-310516-2.pdf.

Eurostat. 2018. Migration and Migrant Population Statistics. Available at: https://ec.europa.eu/eurostat/ statistics-explained/index.php?title=Migration_and_migrant_population_statistics.

Favell, Adrian, Miriam Feldblum and Michael Peter Smith. 2009. "The Human Face of Global Mobility. A Research Agenda". In The Human Face of Global Mobility. International Highly Skilled Migration in Europe, North America and the Asia-Pacific. Michael Peter Smith and Adrian Favell, eds. New Brunswick, London: Transaction Publishers, 1-25.

Glick Schiller, Nina. 2012. "A Comparative Relative Perspective on the Relationships Between Migrants and Cities". Urban Geography 33/6: 879-903. https://doi.org/10.2747/0272-3638.33.6.879

Glick Schiller, Nina and Ayşe Çağlar. 2009. "Towards a Comparative Theory of Locality in Migration Studies. Migrant Incorporation and City Scale". Journal of Ethnic and Migration Studies 35/2: $177-$ 202. https://doi.org/10.1080/13691830802586179

Glick Schiller, Nina and Ayşe Çağlar. 2011. Locating Migration. Rescaling Cities and Migrants. Ithaca, London: Cornell University Press.

Glick Schiller, Nina and Ayşe Çağlar. 2013. “Locating Migrant Pathways of Economic Emplacement. Thinking Beyond the Ethnic Lens". Ethnicities 13/4:494-514. https://doi.org/10.1177/1468796813483733 
Gradski ured za strategijsko planiranje i razvoj Grada. 2012. ZagrebPlan. Razvojna strategija Grada Zagreba. Ciljevi i prioriteti razvoja do 2020. [ZagrebPlan. Development Strategy of the City of Zagreb. Aims and Development Priorities until 2020]. Zagreb: Grad Zagreb, Gradski ured za strategijsko planiranje i razvoj Grada. Available at: https://www.zagreb.hr/UserDocsImages/arhiva/zgplan/ zagrebplan-ciljevi_i_prioriteti_razvoja_do_2020.pdf.

Gradski ured za strategijsko planiranje i razvoj Grada. 2017a. Razvojna strategija Grada Zagreba za razdoblje do 2020. godine [Development Strategy of the City of Zagreb until 2020]. Zagreb: Grad Zagreb, Gradski ured za strategijsko planiranje i razvoj Grada. Available at: https://www.zagreb.hr/UserDocs/mages/gu\%20za\%20strategijsko\%20planiranje/Razvojna\%20strategija\%20 Grada\%20Zagreba_SGGZ_18-17.pdf.

Gradski ured za strategijsko planiranje i razvoj Grada. 2017b. Strategija razvoja Urbane aglomeracije Zagreb za razdoblje do 2020. godine [Development Strategy of the Zagreb Urban Agglomeration until 2020]. Zagreb: Grad Zagreb, Gradski ured za strategijsko planiranje i razvoj Grada. Available at: https://www.zagreb.hr/UserDocsImages/gu\%20za\%20strategijsko\%20planiranje/Strategija\%20 razvoja\%20Urbane\%20aglomeracije\%20Zagreb.pdf.

Gregurović, Margareta, Simona Kuti and Drago Župarić-Iljić. 2016. "Attitudes towards Immigrant Workers and Asylum Seekers in Eastern Croatia. Dimensions, Determinants and Differences". Migracijske i etničke teme 32/1: 91-122. https://doi.org/10.11567/met.32.1.4

HGK - Hrvatska gospodarska komora. 2017. Turizam u 2016. godini [Tourism in 2016]. Zagreb: Hrvatska gospodarska komora, Sektor za financijske institucije, poslovne informacije i ekonomske analize, Odjel za makroekonomske analize. Available at: https://www.hgk.hr/documents/aktualnatema-turizam-u-20165899d9633ad81.pdf.

Horwath HTL. 2011. Strategija turističkog brendiranja grada Zagreba s planom promocije na međunarodnom tržištu. Konačni izvještaj [Tourist Branding Strategy of the City of Zagreb and Plan for its Promotion on the International Market. Final Report]. Available at: http://www.infozagreb.hr/ documents/b2b/TZGZ-Branding-FINAL-291211.pdf.

Horwath HTL. 2016. Strateški i operativni marketinški plan TZGZ 2017.-2020. Prezentacija [Strategic and Operational Marketing Plan of the City of Zagreb Tourist Association 2017-2020. Presentation]. Available at: http://www.infozagreb.hr/documents/b2b/strateskioperativniplan.pdf.

Kekuš, Sara. 2017. "Impact of Migrant Entrepreneurship to Economic Growth". In [MIGRENT]. Migrant (Social) Entrepreneurship as a Tool of Socio-Economic Emancipation of Migrants. Emina Bužinkić, ed. Zagreb: Centre for Peace Studies, Taste of Home, 11-19. Available at: https://www.cms.hr/system/publication/pdf/92/Publikacija_Migrent.pdf.

Kloosterman, Robert C. 2010. "Matching Opportunities with Resources. A Framework for Analysing (Migrant) Entrepreneurship from a Mixed Embeddedness Perspective". Entrepreneurship and Regional Development 22/1: 25-45. https://doi.org/10.1080/08985620903220488

Kloosterman, Robert, Joanne van der Leun and Jan Rath. 1999. "Mixed Embeddedness. (In)formal Economic Activities and Immigrant Businesses in the Netherlands". International Journal of Urban and Regional Research 23/2: 252-266. https://doi.org/10.1111/1468-2427.00194

Kloosterman, Robert C. and Jan Rath. 2001. "Immigrant Entrepreneurs in Advanced Economies. Mixed Embeddedness Further Explored". Journal of Ethnic and Migration Studies 27/2: 189-201. https:// doi.org/10.1080/13691830020041561

Kloosterman, Robert C., Katja Rusinovic and David Yeboah. 2016. "Super-Diverse Migrants - Similar Trajectories? Ghanaian Entrepreneurship in the Netherlands Seen from a Mixed Embeddedness Perspective". Journal of Ethnic and Migration Studies 42/6: 913-932. https://doi.org/10.1080/13 69183X.2015.1126091

Kuti, Simona and Saša Božić. 2011. "Analitičke dimenzije za istraživanje transnacionalnih aktivnosti. Primjer kineskih migranata u Hrvatskoj" [Analytical Dimensions for the Research of Transnational Activi- 
ties. An Example of Chinese Migrants in Croatia]. Revija za sociologiju 41/3: 315-340. https://doi. org/10.5613/rzs.41.3.3

Kuti, Simona and Saša Božić. 2016. Transnacionalni socijalni prostori. Migrantske veze preko granica Hrvatske [Transnational Social Spaces. Migrant Connections across Croatian Borders]. Zagreb: Naklada Jesenski i Turk, Hrvatsko sociološko društvo.

Lekaj, Antoneta, Zrinka Gregov and Mirna Varlandy Supek. 2015. "Temeljne značajke manjinskog poduzetništva na primjeru poduzetništva albanske nacionalne manjine u Hrvatskoj" [The Basic Characteristics of Minority Entrepreneurship. Albanian Entrepreneurs in Croatia]. Obrazovanje za poduzetništvo - E4E 5/2: 69-82.

Međunarodna konferencija Useljenička politika u funkciji razvoja hrvatskoga gospodarstva [International conference entitled Immigration Policy as a Way to Develop Croatian Economy]. 2008. Zagreb: Hrvatska gospodarska komora.

MIPEX - Migrant Integration Policy Index. 2015. Available at: http://www.mipex.eu/croatia.

MT - Ministry of Tourism. 2018. Tourism in Figures 2017. Zagreb: Ministry of Tourism. Available at: https://mint.gov.hr/UserDocsImages/AA_2018_c-dokumenti/180608_HTZTUBENG_2017.PDF.

MUP - Ministarstvo unutarnjih poslova. 2018. Strani državljani [Foreign Nationals]. Available at: https:// www.mup.hr/ministarstvo/dokumenti/statistika.

Nreca, Klaudia and Zrinka Gregov. 2018. "Uloga žena u obiteljskim poduzećima albanske nacionalne manjine u Hrvatskoj" [The Role of Females in the Albanian National Minority Family Business in Croatia]. Obrazovanje za poduzetništvo - E4E 8/special issue: 73-94.

Polančec, Vesna, ed. 2017. Statistical Yearbook of the City of Zagreb for 2017. Zagreb: City of Zagreb, City Office for Strategic Planning and Development of the City, Division for Strategic Information and Research, Department of Statistics. Available at: https://www.zagreb.hr/UserDocsImages/arhiva/ statistika/Book_ZG\%20Ljetopis\%202017_ENG_final.pdf.

Puljiz, Vlado, Josip Tica and Davorko Vidović, eds. 2014. Migracije i razvoj Hrvatske. Podloga za hrvatsku migracijsku strategiju [Migrations and the Development of Croatia. The Basis for a Croatian Migration Strategy]. Zagreb: Hrvatska gospodarska komora.

Rajković Iveta, Marijeta and Rina Geci. 2017. "Kosovar Albanian Goldsmiths and Bakers in Zagreb. Migration and Ethnic Entrepreneurship". Studia ethnologica Croatica 29: 305-330. https://doi. org/10.17234/SEC.29.11

Rath, Jan, Anna Swagerman, Hubert Krieger, Anna Ludwinek and Lisa Pickering. 2011. Promoting Ethnic Entrepreneurship in European Cities. Luxembourg: Publications Office of the European Union. Available at: https://www.eurofound.europa.eu/sites/default/files/ef_publication/field_ef_document/ ef1138en.pdf.

Schwab, Klaus, ed. 2017. The Global Competitiveness Report 2017-2018. Geneva: World Economic Forum. Available at: http://www3.weforum.org/docs/GCR2017-2018/05FullReport/TheGlobalCo mpetitivenessReport2017\%E2\%80\%932018.pdf.

Singer, Slavica, ed. 2017. Small and Medium Enterprises Report Croatia - 2016 Including the Results of GEM - Global Entrepreneurship Monitor Research for Croatia for 2015. Zagreb: CEPOR - SMEs and Entrepreneurship Policy Center. Available at: http://www.cepor.hr/wp-content/uploads/2015/04/ Cepor-izvjesce-2016-ENG-web.pdf.

Singer, Slavica, Nataša Šarlija, Sanja Pfeifer and Sunčica Oberman Peterka. 2017. Što čini Hrvatsku (ne)poduzetničkom zemljom? GEM Hrvatska 2016 [What Makes Croatia a (Non-)Entrepreneurial Country? GEM Croatia 2016]. Zagreb: CEPOR - Centar za politiku razvoja malih i srednjih poduzeća i poduzetništva. Available at: http://www.cepor.hr/wp-content/uploads/2017/05/GEM2016-FINAL-za-web.pdf.

Skupnjak Kapić, Sunčanica. 2014. "Migracije radne snage. Globalni i europski trendovi s osvrtom na Hrvatsku" [Migration of Work Force. Global and European Trends with Reference to Croatia]. In 
Migracije i razvoj Hrvatske. Podloga za hrvatsku migracijsku strategiju [Migrations and the Development of Croatia. The Basis for a Croatian Migration Strategy]. Vlado Puljiz, Josip Tica and Davorko Vidović, eds. Zagreb: Hrvatska gospodarska komora, 217-249.

Štulhofer, Aleksandar and Ivan Burić. 2015. "Je li egalitarni sindrom samo teorijska fantazija? Empirijski hommage Josipu Županovu" [Is the Egalitarian Syndrome a Mere Theoretical Fantasy? An Empirical Hommage to Josip Županov]. Politička misao 52/3: 7-31.

Vankova, Zvezda, Snježana Gregurović and Drago Župarić-lljić, eds. 2014. Hrvatska. Indeks razvijenosti politika integracije migranata (MIPEX). Croatia. A MIPEX Assessment. Zagreb: Institut za migracije i narodnosti. Available at: http://www.imin.hr/c/document_library/get_file?uvid=59d7e46c-51524a8d-ad14-a296e468d6ca\&groupld=10156.

Vertovec, Steven. 2007. "Super-Diversity and Its Implications". Ethnic and Racial Studies 30/6: 10241054. https://doi.org/10.1080/01419870701599465

Župarić-Iljić, Drago and Mario Bara. 2014. “Unutrašnje i vanjske migracije u Hrvatskoj. Povijesni i suvremeni kontekst" [Internal and External Migrations in Croatia. The Historical and Contemporary Context]. In Migracije i razvoj Hrvatske. Podloga za hrvatsku migracijsku strategiju [Migration and the Development of Croatia. The Basis for a Croatian Migration Strategy]. Vlado Puljiz, Josip Tica and Davorko Vidović, eds. Zagreb: Hrvatska gospodarska komora, 197-213.

\section{MJEŠOVITE ETNIČKE I NEETNIČKE EKONOMSKE STRATEGIJE MIGRANATA PODUZETNIKA U ZAGREBU}

Članak analizira male i srednje poduzetničke aktivnosti međunarodnih migranata $\cup$ Zagrebu. Migrantski poslovni projekti u ugostiteljskom sektoru analiziraju se u odnosu prema mogućnostima i ograničenjima $u$ lokalnom i nacionalnom kontekstu te $u$ vezi s nastojanjima grada da se repozicionira u međunarodnim odnosima moći. Autorice pokazuju da dvojaka pozicija grada - kao nacionalne metropole koja kroz razvoj turističkoga sektora nastoji poboljšati svoj nizak položaj u međunarodnim okvirima - ima pozitivne učinke na ekonomsko upisivanje migranata. Ta pozicija grada migrantima nudi šansu za ispunjavanje praznih ekonomskih niša u uslužnom sektoru, čime sudjeluju u trenutnom turističkom boomu i zadovoljavaju povećanu potražnju za različitošću u tom sektoru. Članak pokazuje da lokalni kontekst, koji karakterizira manjak međunarodne različitosti i etničkih tržišta, ne rezultira stvaranjem "etničkih biznisa". Ciljanom klijentelom, zaposlenima, socijalnim mrežama, smještanjem u središtu grada i planovima za ekspanziju poslova migrantski poslovni projekti koriste mješovite, etničke i neetničke, ekonomske strategije upisivanja u grad. Članak stoga naglašava ulogu koju u načinima upisivanja migranata u grad ima specifičan lokalni kontekst; u zagrebačkom slučaju važan dio toga konteksta su napori koje grad ulaže u poboljšanje svoje međunarodne pozicije.

Ključne riječi: međunarodni migranti, migrantsko poduzetništvo, ekonomsko umještanje, stvaranje grada, Zagreb 